\title{
Ground-Level Ozone Production over an Industrial Cluster of China: a Box Model Analysis of a Severe Photochemical Pollution Episode
}

\author{
Xue Yang ${ }^{1,3}$, Xiang Cheng ${ }^{2}$, Huaizhong Yan ${ }^{3}$, Youmin Sun ${ }^{1}$, Guiqin Zhang ${ }^{1 *}$ \\ ${ }^{1}$ College of Municipal and Environmental Engineering, Shandong Jianzhu University, Ji'nan 250101, China \\ ${ }^{2}$ Shandong Zibo Ecological Environment Monitoring Center, Zi'bo 255040, China \\ ${ }^{3}$ Shandong Jinan Ecological Environment Monitoring Center, Ji’nan 250101, China
}

Received: 18 June 2021

Accepted: 21 October 2021

\begin{abstract}
To better understand the characteristics and processes of ozone formation over the industrial cluster of China, intensive field measurements of atmospheric $\mathrm{O}_{3}$, volatile organic compounds (VOCs), and related parameters were conducted in a typical industrialized city of China, Zibo, from July 1 to July 31, 2018. Monitoring data and comparison with other observations revealed severe $\mathrm{O}_{3}$ pollution in Zibo with high frequency $(\sim 55 \%)$ of the non-attainment $\mathrm{O}_{3}$ episodes and high average $\mathrm{O}_{3}$ levels $(\sim 42 \mathrm{ppbv})$. An observation-constrained chemical box model (OBM) was deployed to dissect the $\mathrm{O}_{3}$ formation mechanism and ozone-precursor relationship during a severe photochemical smog episode. $\mathrm{O}_{3}$ was produced by $\mathrm{NO}+\mathrm{HO}_{2}$ and $\mathrm{NO}+\mathrm{RO}_{2}$ reaction and destroyed via the $\mathrm{NO}_{2}+\mathrm{RO}_{2}$ and $\mathrm{NO}_{2}+\mathrm{OH}$ reaction . The observed $\mathrm{O}_{3}$ pollution was dominated by intense in-situ $\mathrm{O}_{3}$ chemical formation with regional transport playing a negative contribution. Sensitivity studies suggested that in situ $\mathrm{O}_{3}$ production was in a VOC-limited or mixed-control regime with aromatics (mainly 1,3,5-Trimethylbenzene and toluene) being the dominant parent hydrocarbons of $\mathrm{O}_{3}$. The OBM and positive matrix factorization (PMF) results indicated that the most efficient way to alleviate the $\mathrm{O}_{3}$ pollution in Zibo is to reduce emissions of aromatics from solvent use, industrial processes and vehicles.
\end{abstract}

Keywords: ozone, industrial VOCs, observation-based model, in situ photochemical formation, aromatics

*e-mail: zhangguiqin320@163.com 


\section{Introduction}

Atmospheric pollution has been sharply increasing over the past three decades due to rapid urbanization and industrialization [1,2]. In particular, chronic ozone $\left(\mathrm{O}_{3}\right)$ exceedances are considered to be the main air pollution problem in China in recent years [3-7]. $\mathrm{O}_{3}$ is a key oxidant and greenhouse gas, and its photolysis leads to hydroxyl radical $(\mathrm{OH})$ formation. $\mathrm{O}_{3}$ also has a detrimental impact on human well-being, vegetation, and regional air quality [8-11]. Therefore, mitigation of $\mathrm{O}_{3}$ pollution in China is important due to its significant role in air quality and climate change.

In principle, photochemical reactions between volatile organic compounds (VOCs) and nitrogen oxides $\left(\mathrm{NO}_{\mathrm{x}}=\mathrm{NO}+\mathrm{NO}_{2}\right)$ control the $\mathrm{O}_{3}$ budget in the low troposphere $[12,13]$. Challenges in mitigation of $\mathrm{O}_{3}$ pollution mainly lie in understanding the non-linear relationship of ozone precursors [14]. As key precursors of $\mathrm{O}_{3}$, VOCs are composed of hundreds of species and have a variety of sources and adverse health effects [15, 16]. Ambient VOCs are emitted directly from various sources, including anthropogenic activities (e.g., motor vehicles and industrial processes) and natural and biomass burning sources [17-19]. In recent years, rapid industrialization in China was accompanied by large emissions of industrial VOCs. Cai et al. [20] reported a considerable contribution of industrial VOCs $(\sim 36 \%)$ to ambient VOCs in Shanghai and An et al. [21] found that industrial emissions contributed $45-63 \%$ of total VOCs in Yangtze River Delta (YRD). Therefore, it is urgent to identify the characteristics of industrial VOCs and their contribution to $\mathrm{O}_{3}$ formation from a regional perspective.

Characterization of VOCs and their effect on $\mathrm{O}_{3}$ has long been carried out in several regions around China [22, 23]. Knowledge of the ozone production regime (VOC-limited vs. NOx-limited) is critical to understanding in-situ ozone production. In the past decade, the observed based model (OBM) based on Master Chemical Mechanism (MCM), Carbon bond IV mechanism (CB5) or Regional Atmospheric Chemical Mechanism (RACM) has been widely used to further understand the $\mathrm{O}_{3}$ photochemistry [4, 24-28]. For instance, using observed based model (OBM), Kanaya et al. [25] examined the net photochemical production rate of $\mathrm{O}_{3}$ at Mount Tai $\left(36.25^{\circ} \mathrm{N}, 117.10^{\circ} \mathrm{E}, 1534 \mathrm{~m}\right.$ above sea level (ma.s.1.)), a typical mountain site over North China Plain (NCP) region and founded that the $\mathrm{O}_{3}$ production regime was typically NOx-limited. Cheng et al. [28] indicated that the $\mathrm{O}_{3}$ production in Guangzhou and Hong Kong was VOC-limited and further selected 12 compounds, i.e., formaldehyde, acetaldehyde, m,p-xylene, toluene, etc., which contributed to $85-89 \%$ $\mathrm{O}_{3}$ formation. Xue et al. [26] analyzed the relationship of ozone $\left(\mathrm{O}_{3}\right)$ and its precursors in four large Chinese cities, namely, Beijing, Shanghai, Guangzhou and Lanzhou, and confirmed that $\mathrm{O}_{3}$ production was in a VOC-limited regime in Beijing, Shanghai and
Guangzhou, and a NOx-limited regime in Lanzhou. Using the MCM simulation, Lyu et al. [29] revealed that $\mathrm{O}_{3}$ production was generally VOC-limited in Wuhan, and that ethene and toluene were the primary contributors to $\mathrm{O}_{3}$ formation. Most previous studies have focused on VOCs and $\mathrm{O}_{3}$ pollution in urban and/or remote areas, while analyses of $\mathrm{VOC}$ and $\mathrm{O}_{3}$ pollution in industrial areas are sparse. In addition, there are some uncertainties in RACM and CB because of the lumping of VOC components having similar chemical structures and activity. Thus, using a model equipped with the Master Chemical Mechanism (MCM version 3.3; http://mcm.leeds.ac.uk/MCM/) is likely most appropriate for simulating in-situ $\mathrm{O}_{3}$ production and exploring the relationships of ozone precursors over industrial cluster in China.

Zibo is one of the most important industrial production bases of Shandong Province in China and is also the main transportation city in the Beijing-TianjinHebei pollution transport channel. It was estimated by the Department of the Ecological Environment of Shandong Province that in 2015, anthropogenic emissions of VOCs were $0.02 \mathrm{Tg}$ in Zibo, ranking third in Shandong Province. Such high emissions over a relatively small land area lead to much higher VOCs emission densities in Zibo compared with other regions (i.e., YRD, $2.77 \mathrm{Tg}$ in 2007 [30]). The objective of this research was to better understand $\mathrm{O}_{3}$ photochemistry in Zibo from July 1 to 31, 2018, through the application of the observation-based model (OBM). In the following discussion, we first provide the temporal variations of $\mathrm{O}_{3}$ and VOCs and make a comparison with other industrial and urban/suburban stations. We then use case studies to examine $\mathrm{O}_{3}$ formation regimes by applying an observation-based model (OBM). Overall, this study highlights the important effect of industrial emissions, in particular, aromatics on in-situ $\mathrm{O}_{3}$ formation and the potential impact to downstream regions over the industrial cluster of China, which may have general implications for understanding the causes of regional secondary pollution in China.

\section{Material and Methods}

\section{Site Description}

The measurement site is an industrial site located in the northern suburb of Zibo (36 $\left.52^{\prime} 21^{\prime \prime} \mathrm{N}-117^{\circ} 58^{\prime} 54^{\prime \prime} \mathrm{E}\right)$, which is surrounded by industrial parks and traffic (see Fig. 1). As shown in Fig. 1, the Zhangdian industrial area is located approximately $1.1 \mathrm{~km}$ southwest of the sampling site. Several industries have a presence in this area, including the chemical, architecture, electronics, and paint industries. The Zhoucun industry area is about $8.9 \mathrm{~km}$ away from the sampling site. This area contains several pollution sources, including pharmaceutical and chemical industries and the printing industry. As the prevailing winds in summer were 

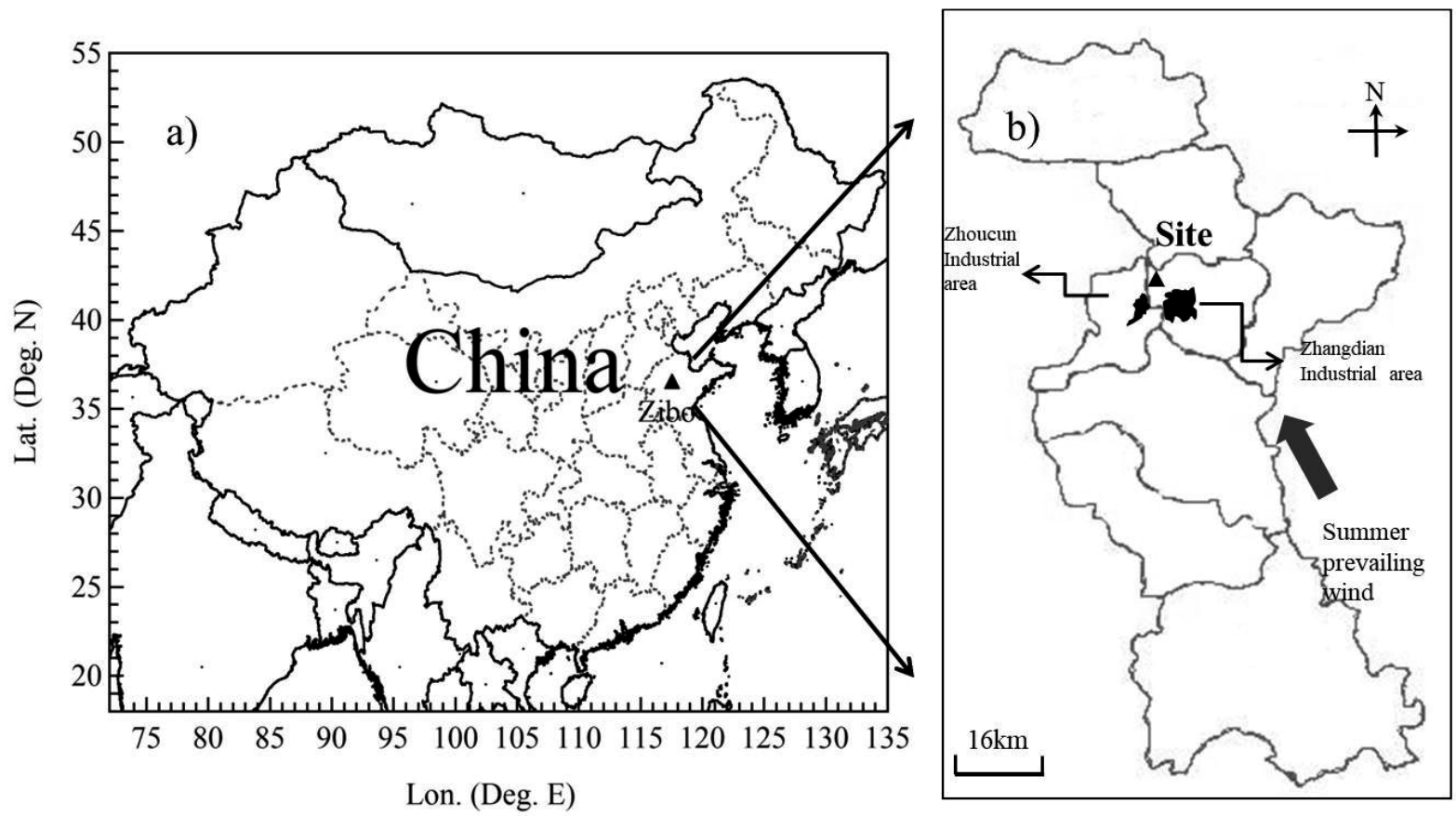

Fig. 1. a) Map showing the locations of the Zibo and satellite (SCIAMACHY and GOME-2(B))-retrieved formaldehyde column in China, and b) the location of the sampling site in Zibo. Note that industrial areas are shown in red.

from the south/southeast under the influence of the Asian monsoon, the study site is downwind of the above two industrial areas.

\section{Instruments and Data}

$\mathrm{O}_{3}, \mathrm{O}_{3}$ precursors as well as meteorological parameters were continuously measured from July 1 to July 31, 2018 by a set of techniques after strict quality control. In brief, $\mathrm{O}_{3}$ was measured by a commercial ultraviolet absorption analyser (Thermo 49i, US); $\mathrm{NO}_{\mathrm{x}}$ with a chemiluminescence analyser with a molybdenum oxide converter (Thermo 42i, US); $\mathrm{CO}$ by a non-dispersive infrared analyser (Thermo 48i, US). Meteorological parameters including temperature, relative humidity (RH), wind speed and direction were continuously recorded by an automatic weather station (MILOS520, Vaisala, Finland). 55 VOC species, including 29 alkanes, 9 alkenes, 16 aromatics and 1 alkyne (ethyne) were measured and quantified by commercial automatic GC5000 analysis systems (see Table 1). The VOCs measurements were conducted online throughout the observation period with the time resolution of $1 \mathrm{~h}$. To ensure the accuracy of test data, the instrument is calibrated before monitoring with the standard photochemical gas for ozone precursors approved by the US Environmental Protection Agency (EPA) Photochemical Assessment monitoring Station (PAMS). Five-level calibration curves were used to calibrate the equipment and quantify the VOC concentrations during the whole campaign. During the calibration, the correlation coefficient was between 0.992 and 0.999 . The detection limits of those measured
VOCs ranged from 3 to $50 \mathrm{pptv}$. The detailed description of quality assurance and control procedures of all the above instruments has been described in many previous studies (e.g., An et al. [21] and Zou et al. [31]).

\section{Observation-Based Model (OBM)}

The Observation-based model (OBM) based on the newest version of the MCM is a robust tool for explicit simulation of atmospheric chemistry and describes $\sim 17000$ chemical reactions of individual VOCs [32, 33]. The model is a zero-dimensional chemical box model which includes homogeneous chemistry, heterogeneous chemical processes, dry deposition, and dilution mixing within the boundary layer and has been successfully applied to simulate $\mathrm{O}_{3}$ formation, PAN production, atmospheric oxidative capacity, ROx chemistry and carbonyls secondary formation [34-37]. Specifically, dry deposition of gases and VOCs was adopted in our model with dry deposition velocities taken form Zhang et al. [38]. In addition, the dilution mixing within the boundary layer for all species was applied in the model with the boundary layer height being assumed to be $300 \mathrm{~m}$ at night and linearly rise to $1500 \mathrm{~m}$ in the early afternoon. Sensitivity tests by changing maximum PBL heights (e.g., $1000 \mathrm{~m}$ and $2000 \mathrm{~m}$ ) has been conducted in our previous study [36], which indicated negligible impacts (i.e., $<3 \%$ to net carbonyls production rates) on the modeling conclusion. Here, we use observed $\mathrm{O}_{3}$ and its precursors as well as related meteorological parameters to simulate the rates and regimes of photochemical $\mathrm{O}_{3}$ production. Specially, the model reads in the observation data every hour to calculate 
Table 1. Statistics of major VOC species measured at Ziboa.

\begin{tabular}{|c|c|c|c|c|}
\hline Category & \multicolumn{4}{|c|}{ Species } \\
\hline \multirow{8}{*}{ Alkanes(29) } & 2-methylpentane & n-decane & Ethane & 2,4-dimethylpentane \\
\hline & n-hexane & Propane & n-undecane & 2,2-dimethylbutane \\
\hline & 2,2,4-trimethylpentane & i-butane & n-dodecane & 2,3-Dimethylbutane \\
\hline & n-heptane & n-butane & Methylcyclopentane & Cyclohexane \\
\hline & 2,3,4-trimethylpentane & Cyclopentane & 3-methylpentane & 2-methylheptane \\
\hline & Methylcyclohexane & i-pentane & 3-methylhexane & 3-methylheptane \\
\hline & n-octane & n-pentane & 2-methylhexane & 2,3-dimethylpentane \\
\hline & n-nonane & & & \\
\hline 11 - & Propene & i-butene & 1-butene & Cis-2-butene \\
\hline Aाкеाट्ड (ग) & i-pentene & 1-pentene & Cis-2-pentene & Isoprene \\
\hline & Ethene & & & \\
\hline Alkyne(1) & Ethyne & & & \\
\hline & Benzene & Ethylbenzene & o-Xylene & $\mathrm{m} / \mathrm{p}$-Xylene \\
\hline Aromatics 16$)$ & Toluene & m-ethyltoluene & p-ethyltoluene & o-ethyltoluene \\
\hline Aromialics (10) & n-Propylbenzene & 1,3,5-Trimethylbenzene & 1,2,4-Trimethylbenzene & 1,2,3-Trimethylbenzene \\
\hline & m-diethylbenzene & p-diethylbenzene & Styrene & i-propylbenzene \\
\hline
\end{tabular}

${ }^{a}$ All of these species were used to constrain the MCM box model.

the in-situ rates of $\mathrm{O}_{3}$ production and loss. The net $\mathrm{O}_{3}$ production rate $\left(\mathrm{Net} P\left(\mathrm{O}_{3}\right)\right.$ ) can be estimated from the $\mathrm{P}\left(\mathrm{O}_{3}\right)$ and $\mathrm{L}\left(\mathrm{O}_{3}\right)$. The corresponding rates can be determined from the following equations:

$$
P\left(\mathrm{O}_{3}\right)=k_{1 i}\left[\mathrm{HO}_{2}\right][\mathrm{NO}]+\sum\left(k_{2 i}\left[\mathrm{RO}_{2}\right][\mathrm{NO}]\right)
$$

$L\left(\mathrm{O}_{3}\right)=k_{3}\left[\mathrm{O}^{1}(\mathrm{D})\right]\left[\mathrm{H}_{2} \mathrm{O}\right]+\left\{k_{4}[\mathrm{OH}]+k_{5}\left[\mathrm{HO}_{2}\right]+\sum k_{6 i}\left[\mathrm{VOC}_{i}\right]\right\}\left[\mathrm{O}_{3}\right]$ $+k_{7}[\mathrm{OH}]\left[\mathrm{NO}_{2}\right]+k_{8 i}\left[\mathrm{RO}_{2}\right]\left[\mathrm{NO}_{2}\right]+2 \sum\left(k_{9 i}\left[\mathrm{VOC}_{i}\right]\left[\mathrm{NO}_{3}\right]\right)$

+3heter.loss $\mathrm{N}_{205}+2$ Heter.loss $\mathrm{NO}_{\mathrm{N}}$

$$
\text { Net } \mathrm{P}\left(\mathrm{O}_{3}\right)=\mathrm{P}\left(\mathrm{O}_{3}\right)-L\left(\mathrm{O}_{3}\right)
$$

Where $\mathrm{RO}_{2}$ is the representative of organic peroxy radicals (e.g. $\mathrm{C}_{2} \mathrm{H}_{5} \mathrm{O}_{2}$ ), $\mathrm{VOC}_{i}$ represents unsaturated NMHC species, $\mathrm{k}$ represent related reaction rate coefficients. In addition to gas phase reactions, heterogeneous processes regarding $\mathrm{N}_{2} \mathrm{O}_{5}$ and $\mathrm{NO}_{3}$ loss were also included in our model. Note the kinetic data are obtained from the IUPAC database (http://iupac. pole-ether.fr/index.html). In particular, the OBM model simulated $\mathrm{O}_{3}$ and reactive carbonyls (e.g. HCHO) with constraints of VOC precursors agree well with the observed diurnal patterns by Xue et al. [37] and Yang et al. [36], indicating their dominate secondary source and suggesting the OBM is capable of simulating the concentrations of observed highly reactive species.

In detail, the model was constrained by the intensive set of observations to represent the measured real atmospheric conditions. For instance, the observed concentrations of $\mathrm{O}_{3}, \mathrm{VOCs}, \mathrm{CO}, \mathrm{NO}, \mathrm{NO}_{2}, \mathrm{SO}_{2}$, temperature and $\mathrm{H}_{2} \mathrm{O}$ were processed (averaged or interpolated) into the model inputs with a time resolution of 1 hour and used to constrain the model. The model calculations were performed for one smog episode with concentrations of $\mathrm{O}_{3}$ exceeding the ambient air quality standard (i.e., 2 to 5 July 2018). In the base run, the model calculation started from 00:00 local time and runs for a $24 \mathrm{~h}$ period. The model was run five times to stabilize the simulation of the unconstrained compounds and the outputs of the last run were subject to further analyses. Detailed information about the model configuration and calculation of the $\mathrm{O}_{3}$ production rate has been described elsewhere [39].

\section{Results and Discussion}

\section{Characteristics of Ozone Pollution}

Fig. 2 shows the measured time series of $\mathrm{O}_{3}$ pollution and meteorological conditions at Zibo during the intensive campaign. Weather conditions consisted of relatively high temperatures (with average \pm standard deviation of $29.5 \pm 3.6^{\circ} \mathrm{C}$ ) and moderate relative humidity (72.6 $\pm 12.4 \%$ ). During 2-5 July (four days), Zibo was hit by one prolonged photochemical smog episode during the early stages of sampling period with peak $\mathrm{O}_{3}$ value exceeding the national ambient air quality standards 


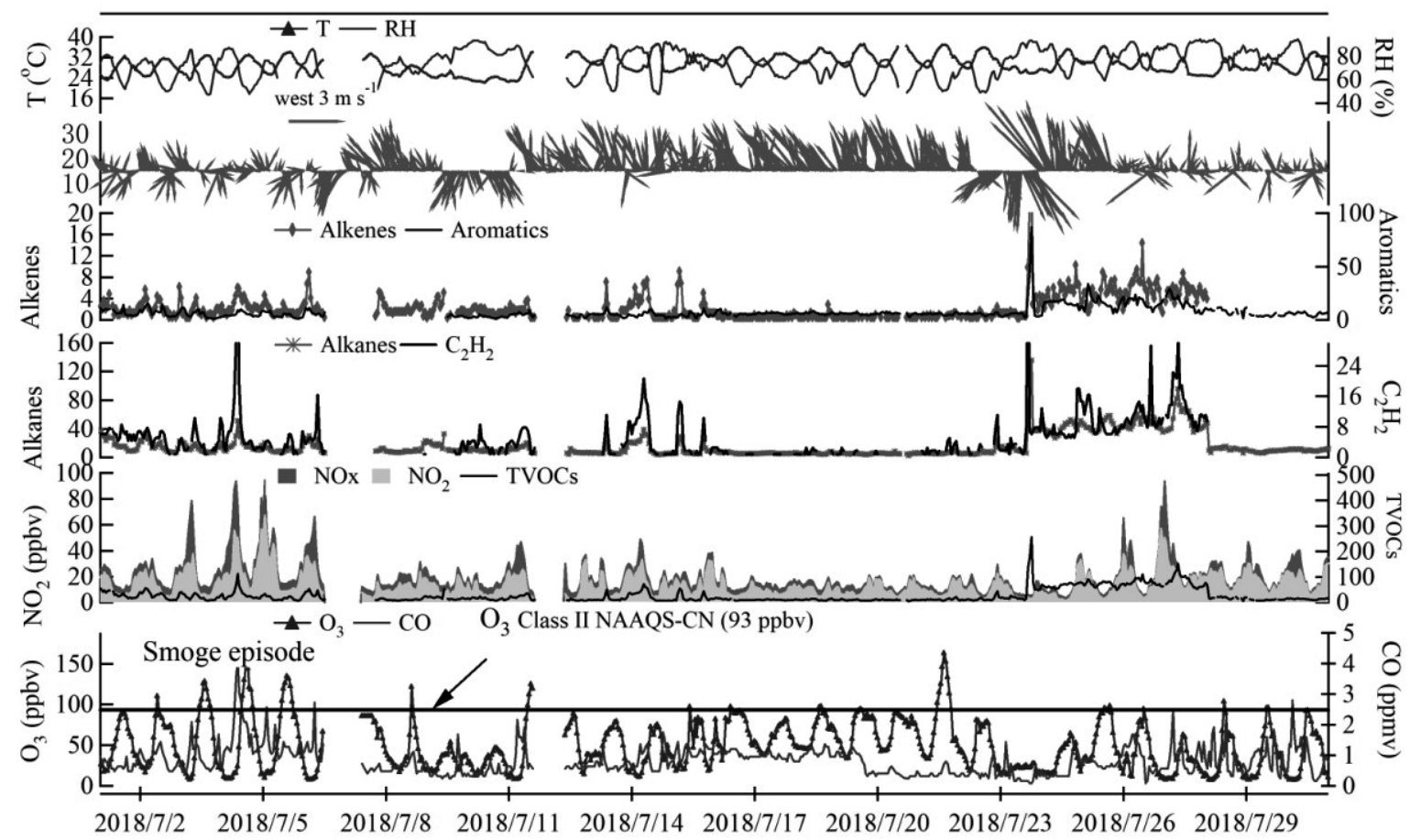

Fig. 2. Time series of $\mathrm{O}_{3}$ and related trace gases together with meteorological parameters at Zibo from 1 July to 31 July, 2018. The units are ppbv except CO. The shaded areas correspond to the multi-day photochemical episode, which were subject to the detailed modeling analysis. The data gaps were mainly due to the calibration and maintenance of the instruments.

of China (Class II: 93 ppb for hourly values), when high temperature and lower $\mathrm{RH}$ persisted, which is representative of local Zibo pollution. The zoomedin figure of this episode is given in Fig. S1. The peak value of $\mathrm{O}_{3}$ was recorded at 163 ppbv on 4 July, 2018. In comparison, relatively low $\mathrm{O}_{3}$ levels were observed during the middle and later period of the campaign accompanied with relatively lower temperatures $\left(28.5 \pm 3.7^{\circ} \mathrm{C}\right)$ and higher RH $(80.1 \pm 9.2 \%)$. However, the high NOx and VOCs values (19.60 and 66.27 ppbv) were observed during 25-28 July, 2018, which may be interpreted as the weakened local photochemistry with lower RH levels and temperatures described above. Obviously, the inspection of observational data shows the serious situation of summertime ozone pollution over the industrial cluster of China during the smog episode.

Fig. 3 shows the average diurnal profiles of $\mathrm{O}_{3}$, total VOCs (TVOCs), related trace gases, and meteorological parameters at Zibo derived from the measurements. This figure illustrates the well-defined unimodal profile for diurnal variations of $\mathrm{O}_{3}$ in the polluted industrial environments. The mean $\mathrm{O}_{3}$ mixing ratios were at a minimum of $\sim 21 \mathrm{ppbv}$ at 05:00 LT (local time) and a maximum of $\sim 83$ ppbv at 14:00 LT. The broad peak in $\mathrm{O}_{3}$ concentrations during the afternoon and the dramatic average daytime $\mathrm{O}_{3}$ build-up (i.e., 62 ppbv) indicate the strong in situ ozone production during daytime in the study area. The mean values for $\mathrm{NO}_{\mathrm{x}}$ showed a unimodal profile with a predominant peak ( 28 ppbv) at 06:00 LT. Meanwhile, NOx concentrations were high ( $\sim 25 \mathrm{ppb})$ at night, which was likely due to the shallow boundary layer and enhanced truck emissions during the night. In comparison, the NOx values in daytime were low, which may attribute to not only the deeper boundary layer but also the reaction with $\mathrm{OH}$ and $\mathrm{RO}_{2}$ as well as self-photolysis. $\mathrm{CO}$ exhibited a less significant diurnal pattern (with a mean value in the range of 0.66-0.99 ppmv). In contrast, as shown in Fig. 3, the TVOCs exhibited a bimodal pattern, i.e, morning (08:00-09:00 LT), afternoon maxima (16:00-18:00) and noon minimum (14:00-15:00) due to increased photochemical activity during the daytime. Such results were similar to the pattern observed in a typical petrochemical area of Shanghai [40]. Overall, an inspection of diurnal variations clearly indicates the strong photochemical ozone formation at Zibo.

\section{Composition of Observed VOCs and Comparison with other Locations}

As mentioned above, markedly severe $\mathrm{O}_{3}$ pollution was observed at Zibo during the sampling period. Individual VOC compounds have different photochemical reactivities and $\mathrm{O}_{3}$ formation capacity. Therefore, we examined the VOCs compositions and reactivities obtained at Zibo during the summer campaign in this section to evaluate the contributions of the individual VOCs to ozone production. Concentration levels and photochemical properties i.e., $\mathrm{OH}$ reactivity $\left(R_{O H}\right)$ of 55 VOC species measured at Zibo were 


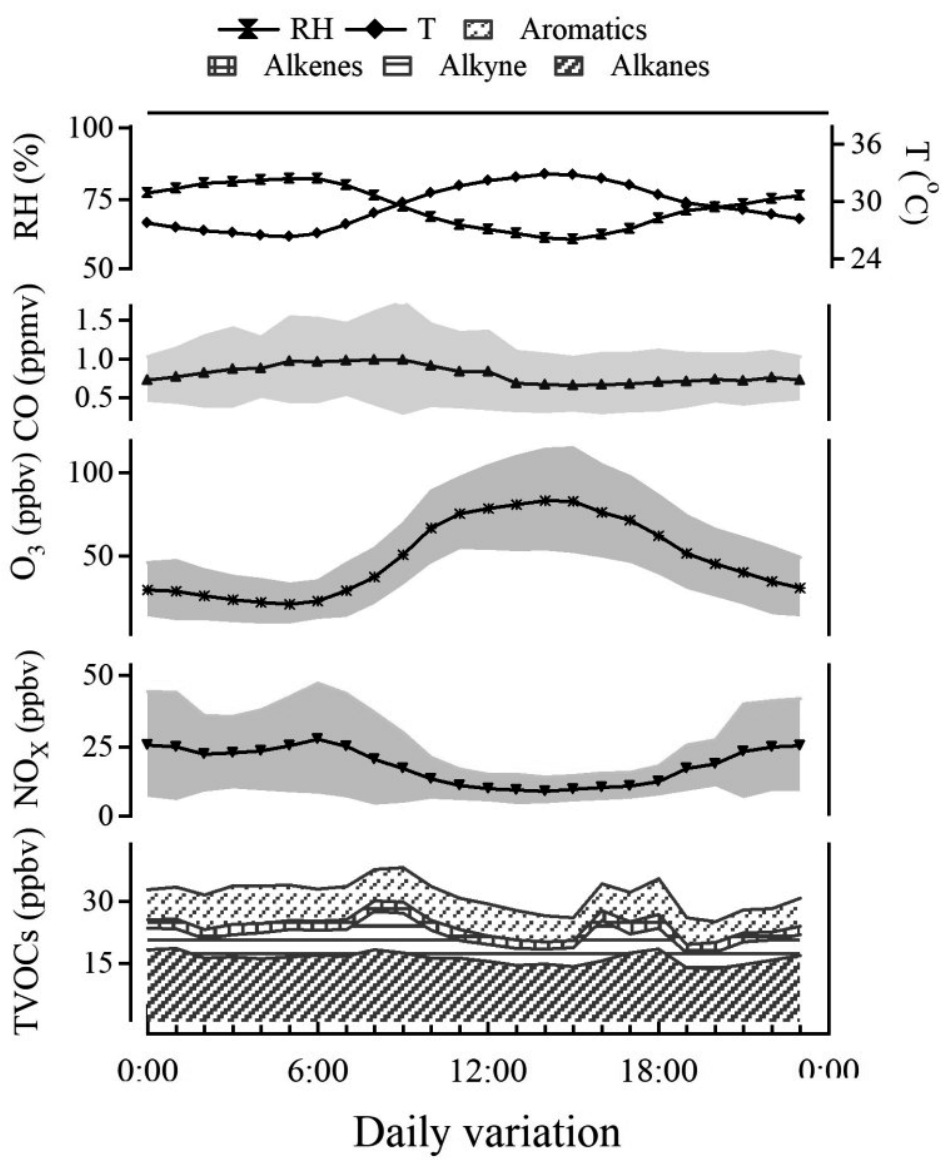

Fig. 3. Diurnal patterns of $\mathrm{O}_{3}$ and related pollutants (i.e., $\mathrm{NO}_{\mathrm{X}}, \mathrm{CO}$ and TVOCs) at Zibo. Vertical bars represent standard errors.

calculated and depicted in Fig. 4. As depicted in Fig. 4, during the whole campaign, the average concentrations of alkanes, alkenes, alkynes, and aromatics were $16.29,2.66,5.52$ and $7.28 \mathrm{ppbv}$, respectively. The three most abundant VOCs were ethane (5.16 ppbv), ethyne (3.50 ppbv) and m-diethylbenzene (12.36 ppbv), representing $43 \%$ of the total VOCs measured. The $R_{O H}$ of a particular VOCs was calculated as the product of its concentration and its rate constant for reaction with $\mathrm{OH}: R_{\mathrm{OH}}=\left[\mathrm{VOC}_{i}\right] \times K_{\mathrm{OH}}$. The total hydrocarbon reactivity for the study was $6.13( \pm 0.09) \mathrm{s}^{-1}$ at Zibo, which is comparable to those measured many urban areas, such as Shanghai $\left(5.85 \mathrm{~s}^{-1}\right)$, Guangzhou $\left(5.23 \mathrm{~s}^{-1}\right)$ and Lanzhou $\left(9.33 \mathrm{~s}^{-1}\right)$ [26], while much higher than Yucheng $\left(2.07 \mathrm{~s}^{-1}\right)$, a rural site downwind of Ji'nan [41]. Furthermore, ozone formation potential (OFP) were also calculated to evaluate the contributions of the individual VOCs to ozone production with an average of $284.67 \mu \mathrm{g} \mathrm{m}^{-3}$, which is much higher than that measured in the industrial area of Brazil [42]. This clearly indicates that the reactive VOCs are quite high at Zibo, most probably due to a large number of industrial sources near the study site. Based on the $\mathrm{OH}$ reactivity calculation result, aromatics were the most important reactive VOCs group at Zibo and accounted for 39\% of the total hydrocarbon reactivity. For the particular reactive aromatics, the most significant species were 1,3,5-Trimethylbenzene $\left(0.88 \mathrm{~s}^{-1}\right)$ with a mean contribution of $14 \%$ on average, of the hydrocarbon reactivity, followed by styrene $\left(0.60 \mathrm{~s}^{-1} ; 10 \%\right)$. Isoprene was the most reactive biogenic hydrocarbon with an average $R_{O H}$ value of $0.88 \mathrm{~s}^{-1}$ and contribution of $14 \%$.

For a better understanding of the $\mathrm{O}_{3}$ and VOCs pollution situations at Zibo, we compare the $\mathrm{O}_{3}$, TVOC concentrations and dominant types of VOCs at Zibo with those measured in other industrial, urban, and suburban locations (see Table 2). The average concentration of TVOCs is within the range reported for other industrial environments. In general, the concentrations of TVOCs at Zibo were higher than those measured in industrial areas of Houston [43], but lower than Nanjing [44] and Lanzhou [45]. Generally, the absolute concentration of VOCs and $\mathrm{O}_{3}$ is affected by many factors, e.g., sampling site, time, environmental and meteorological conditions. The higher VOCs and $\mathrm{O}_{3}$ concentrations in Lanzhou are uniquely due to its valley topography [45]. What's more, compared with urban/ suburban areas, the VOCs value was lower than those in Beijing [46], Tianjin [47], Guangzhou [31] and Hong Kong [48] but was comparable to the result obtained in Wuhan (see Table 2). In addition, the dominant VOCs file was similar in both industry and urban sites, and the high abundant aromatics suggest that the solvent usage would be important sources at Zibo. Table 2 also shows that the average and maximum $\mathrm{O}_{3}$ concentrations at Zibo are generally greater than those reported by 

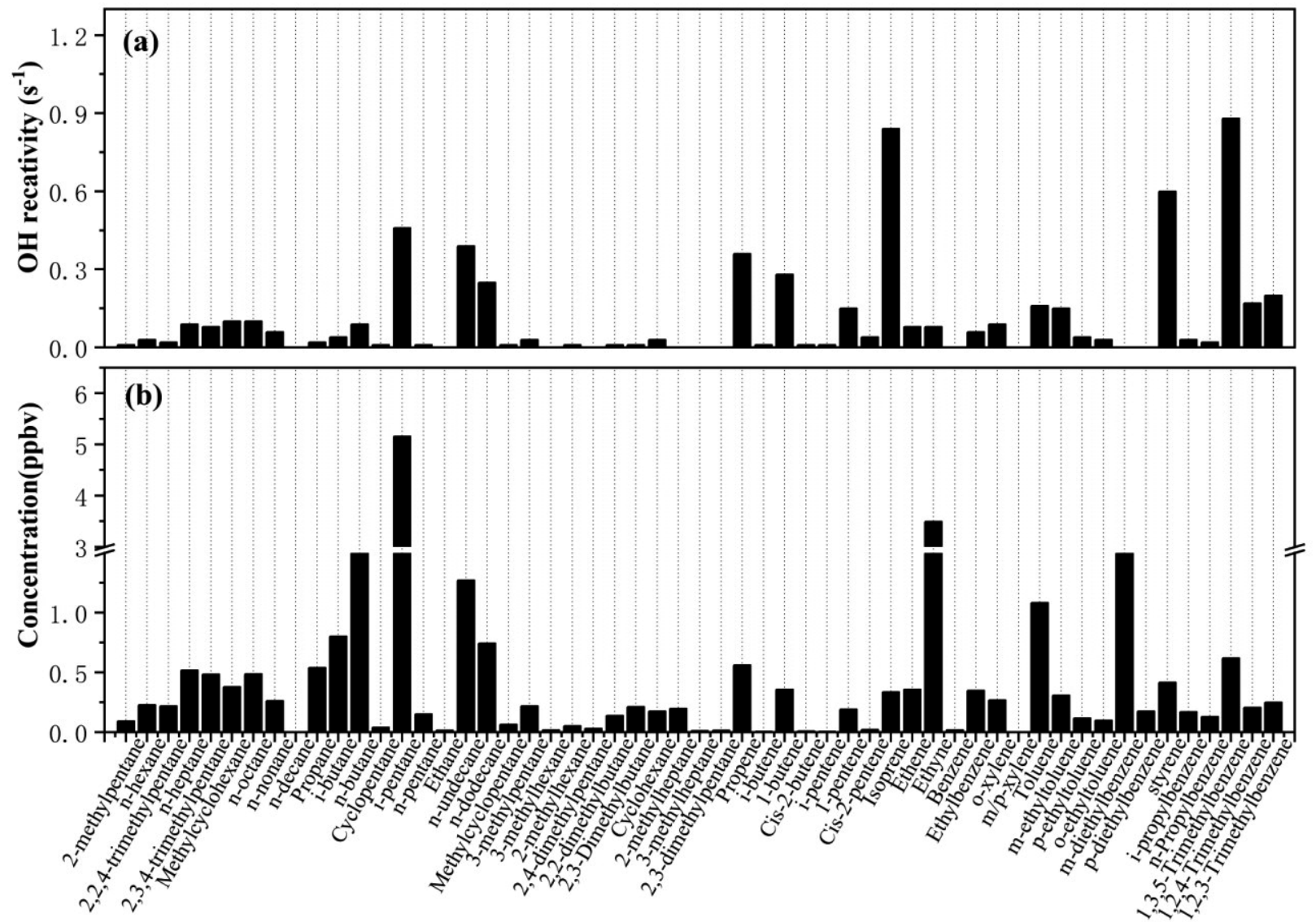

Fig. 4. a) OH reactivity and b) corresponding concentration of individual VOCs (in unit of ppbv).

the studies conducted in other urban, industrial, and suburban locations, which highlights the severity of photochemical pollution over Zibo.

The Process Analysis of Ozone Episode

The aforementioned analysis qualitatively revealed the effects of in situ photochemical production to the observed ozone pollution at Zibo. In this section, we further evaluate the chemical budgets of $\mathrm{O}_{3}$ using a detailed case study with the aid of the OBM model. The detailed measurement data of $\mathrm{O}_{3}$ and meteorological parameters in this episode (i.e., 2 to 5 July 2018) are depicted in Fig. S1. During this episode, the atmosphere was characterized by persistent high ozone concentrations (in the range of 111-163 ppbv) and high NOx ( $\sim 30$ ppbv as the daytime average). Meanwhile, the VOCs concentration on 4 July was

Table 2. Comparison of VOCs and $\mathrm{O}_{3}$ concentrations at Zibo with observations at other locations in other regions.

\begin{tabular}{|c|c|c|c|c|c|c|c|c|}
\hline Location & $\begin{array}{c}\text { Sites } \\
\text { category }\end{array}$ & $\begin{array}{c}\text { Sampling } \\
\text { period }\end{array}$ & $\begin{array}{c}\text { TVOCs } \\
(\mathrm{ppbv})\end{array}$ & Alkanes & Alkenes & Aromatics & $\begin{array}{c}\mathrm{O}_{3} \text {-average } \\
(\mathrm{ppbv})\end{array}$ & $\begin{array}{c}\mathrm{O}_{3} \text {-maximum } \\
(\mathrm{ppbv})\end{array}$ \\
\hline Zibo & Industrial & Jul. 2018 & 31.75 & 16.29 & 2.66 & 7.28 & 42 & 163 \\
\hline Nanjing [44] & Industrial & May-Aug.2013 & 34.40 & 14.98 & 7.35 & 9.06 & 32 & 146 \\
\hline Houston [43] & Industrial & Aug-Sep. 2006 & 20.45 & - & - & - & - & - \\
\hline Lanzhou [45] & Industrial & Feb-Mar. 2017 & 50.05 & - & - & - & - & - \\
\hline Wuhan [29] & Urban & Feb 2013-Oct 2014 & 24.3 & 13.3 & 4.3 & 4.8 & 48 & - \\
\hline Beijing [46] & Urban & Jun-Sep.2007 & 149 & 73.16 & 22.80 & 48.87 & 47 & 275 \\
\hline Tianjin [47] & Urban & Jul-Sep. 2009 & 87.91 & - & - & - & - & 130 \\
\hline Guangzhou [31] & Suburban & Jun 2011-May 2012 & 40.58 & 26.06 & 6.8 & 11.7 & 26 & - \\
\hline Hong Kong [48] & Suburban & Oct-Dec.2007 & 34 & - & - & - & 32 & - \\
\hline
\end{tabular}




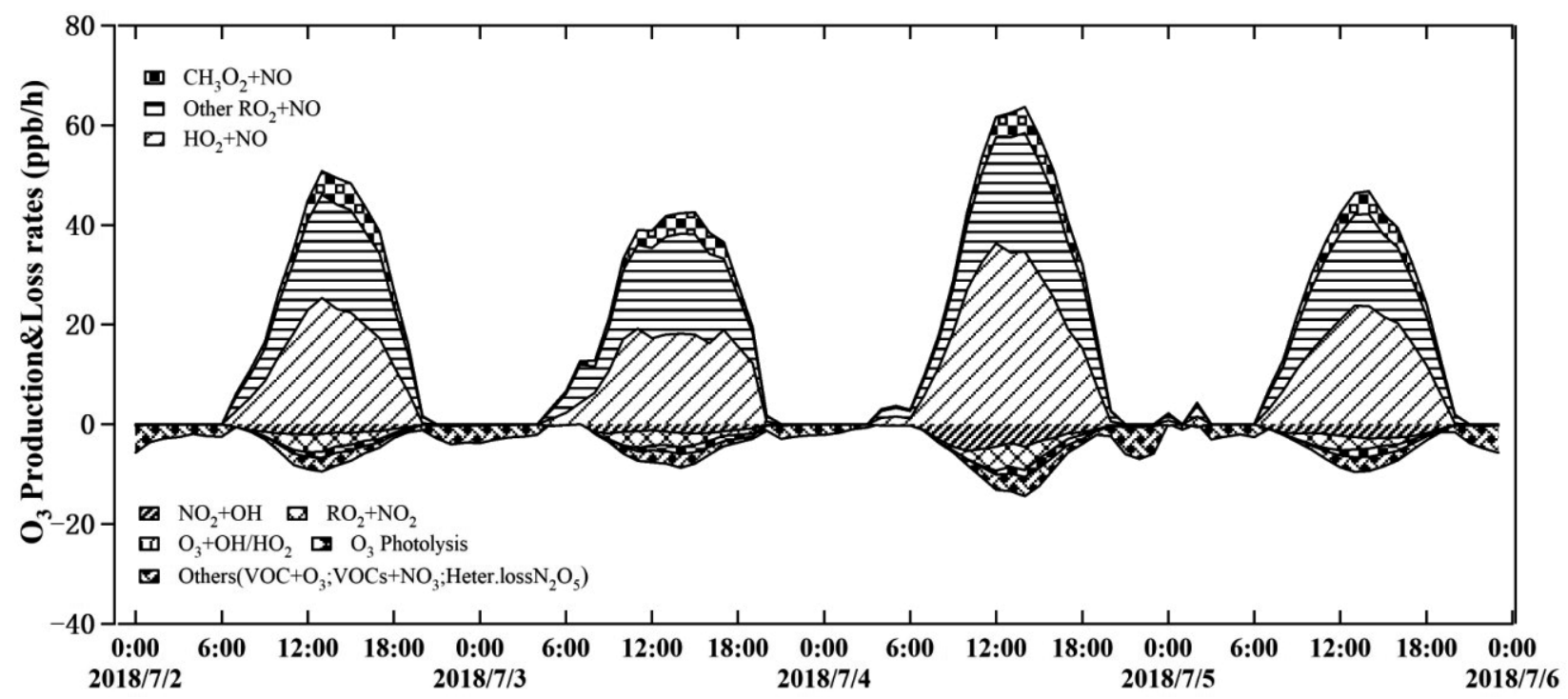

Fig. 5. Model-simulated in situ $\mathrm{O}_{3}$ production and destruction terms at Zibo on 2-5 July, 2018.

higher than in other days, which may have contributed to the very high afternoon $\mathrm{O}_{3}$ concentrations of approximately $160 \mathrm{ppb}$ observed on that day.

To quantify the role of photochemistry formation in the chemical $\mathrm{O}_{3}$ budget, the in situ $\mathrm{O}_{3}$ production rate and destruction rate was calculated by the observationbased model. The in situ day-by-day variations of model-computed $\mathrm{O}_{3}$ production, destruction and net rates for this episode are presented in Fig. 5. The model simulated average $\mathrm{O}_{3}$ production rate $(\sim 30.4-41.2 \mathrm{ppb} / \mathrm{h})$ during the 2-5 July 2018 is much higher than that of $\mathrm{O}_{3}$ loss rate $(\sim 5.1-8.0 \mathrm{ppb} / \mathrm{h})$, indicative of net $\mathrm{O}_{3}$ production in this episode. Fig. 5 also shows the breakdown of the ozone production and loss pathways simulated in this episode at Zibo. In general, all four case days showed similar $\mathrm{O}_{3}$ formation and destruction mechanisms. The $\mathrm{O}_{3}$ production is dominated by the reaction of NO with $\mathrm{HO}_{2}$, which accounts for $\sim 47 \%$ (i.e. $15.2 \mathrm{ppb} / \mathrm{h}$ ), $\sim 50 \% \quad(17.7 \mathrm{ppb} / \mathrm{h}), \quad 55 \% \quad(23.0 \mathrm{ppb} / \mathrm{h})$ and $\sim 56 \%$ $(15.3 \mathrm{ppb} / \mathrm{h})$ of the total $\mathrm{O}_{3}$ production for $2-5 \mathrm{July}$, respectively and the remaining ( $\sim 53 \%$ (or $16.6 \mathrm{ppb} / \mathrm{h}$ ), $\sim 50 \% \quad(16.0 \mathrm{ppb} / \mathrm{h}), \sim 45 \% \quad(18.6 \mathrm{ppb} / \mathrm{h})$ and $\sim 51 \%$ $(15.2 \mathrm{ppb} / \mathrm{h})) . \mathrm{O}_{3}$ production is due to the NO oxidation by $\mathrm{RO}_{2}$, with $\mathrm{CH}_{3} \mathrm{O}_{2}$ alone contributing $10 \%(3.2 \mathrm{ppb} / \mathrm{h})$, $8 \%(2.7 \mathrm{ppb} / \mathrm{h}), 8 \%(3.3 \mathrm{ppb} / \mathrm{h})$ and $10 \%(3.0 \mathrm{ppb} / \mathrm{h})$. For the $\mathrm{O}_{3}$ loss terms, the dominant pathway is the $\mathrm{NO}_{2}+\mathrm{OH}$ reaction to form nitric acid $\left(\mathrm{HNO}_{3}\right)(38 \%$ (or $1.4 \mathrm{ppb} / \mathrm{h}), 26 \%(1.2 \mathrm{ppb} / \mathrm{h}), 48 \%(3.2 \mathrm{ppb} / \mathrm{h})$ and $47 \%(2.0 \mathrm{ppb} / \mathrm{h})$, respectively), followed by reaction of $\mathrm{NO}_{2}$ with $\mathrm{RO}_{2}$, with average contributions of $12 \%$ (or $1.7 \mathrm{ppb} / \mathrm{h}), 11 \%(1.6 \mathrm{ppb} / \mathrm{h}), 9 \%(2.2 \mathrm{ppb} / \mathrm{h})$ and $11 \%$ $(1.4 \mathrm{ppb} / \mathrm{h})$, respectively. This indicates the potential intensive formation of organic nitrates and $\mathrm{HNO}_{3}$ at Zibo. Indeed, high levels of fine particulate nitrate in $\mathrm{PM}_{25}$ in the NCP have been reported by Wen et al. [49], who indicated that controlling $\mathrm{NOx}$ and $\mathrm{O}_{3}$ is an efficient way to mitigate nitrate pollution. Wang et al. [50] measured fine particulate nitrated phenols and reflect the important role of secondary formation to nitrated phenols in remote areas of NCP.

In general, the change of observed $\mathrm{O}_{3}$ concentrations is subjected to three factors: in-situ photochemistry (production or destruction), regional transport (import or export) and deposition. Using the observation-based model (OBM), the relative contributions of these factors can be estimated, which has been reported by Xue et al. [26]. Specifically, the change rate of $\mathrm{O}_{3}$ concentrations can be obtained from our observed $\mathrm{O}_{3}$ time series $\left(R_{\text {meas }}\right)$; the in situ net $\mathrm{O}_{3}$ chemical formation rate $\left(R_{\text {chem }}\right)$ and deposition rate $\left(R_{\text {deps }}\right)$ can be estimated by the OBM model; therefore, the regional transport rate $\left(R_{\text {trans }}\right)$, which includes not only the horizontal and vertical transport but also the atmospheric effects, can be obtained by subtracting (i.e., $R_{\text {trans }}=R_{\text {meas }}-R_{\text {chem }}-R_{\text {deps }}$ ).

Fig. 6 presents the contribution of in-situ photochemistry, regional transport and deposition at Zibo on 2-5 July, 2018. Similar to Fig. 5, Fig. 6 shows that net $\mathrm{O}_{3}$ production occurred during daytime throughout this episode. In addition, we found an interesting phenomenon that in the early morning, $\mathrm{O}_{3}$ accumulated rapidly owing to the import of $\mathrm{O}_{3}$ rich air aloft from the residual boundary-layer air. The import of $\mathrm{O}_{3}$-rich air aloft contributed $\sim 1.1$ to $\sim 4.2 \mathrm{ppbv}$ of the observed $\mathrm{O}_{3}$ accumulation in the morning. Statistically, the daytime average (07:0018:00 LT) net $\mathrm{O}_{3}$ production rates were calculated as 26.7, 28.6, 33.6 and $24.9 \mathrm{ppb} / \mathrm{h}$ for 2-5 July 2018, respectively. Such levels are of the same magnitude as the modeled rates at suburbs downwind of Shanghai and Guangzhou (25 and $30 \mathrm{ppb} / \mathrm{h}$, respectively; [26]) as well as Zhuhai (16 ppb/h, [51]), but are much higher than those obtained at a rural site downwind of Beijing (4.3 ppb/h; [36]) and Mt. Tai (6.4 ppb/h; [25]). This is as expected due to the higher abundance of $\mathrm{O}_{3}$ precursors at Zibo. The locally produced amounts of $\mathrm{O}_{3}$, as estimated by integrating the in situ production rates 


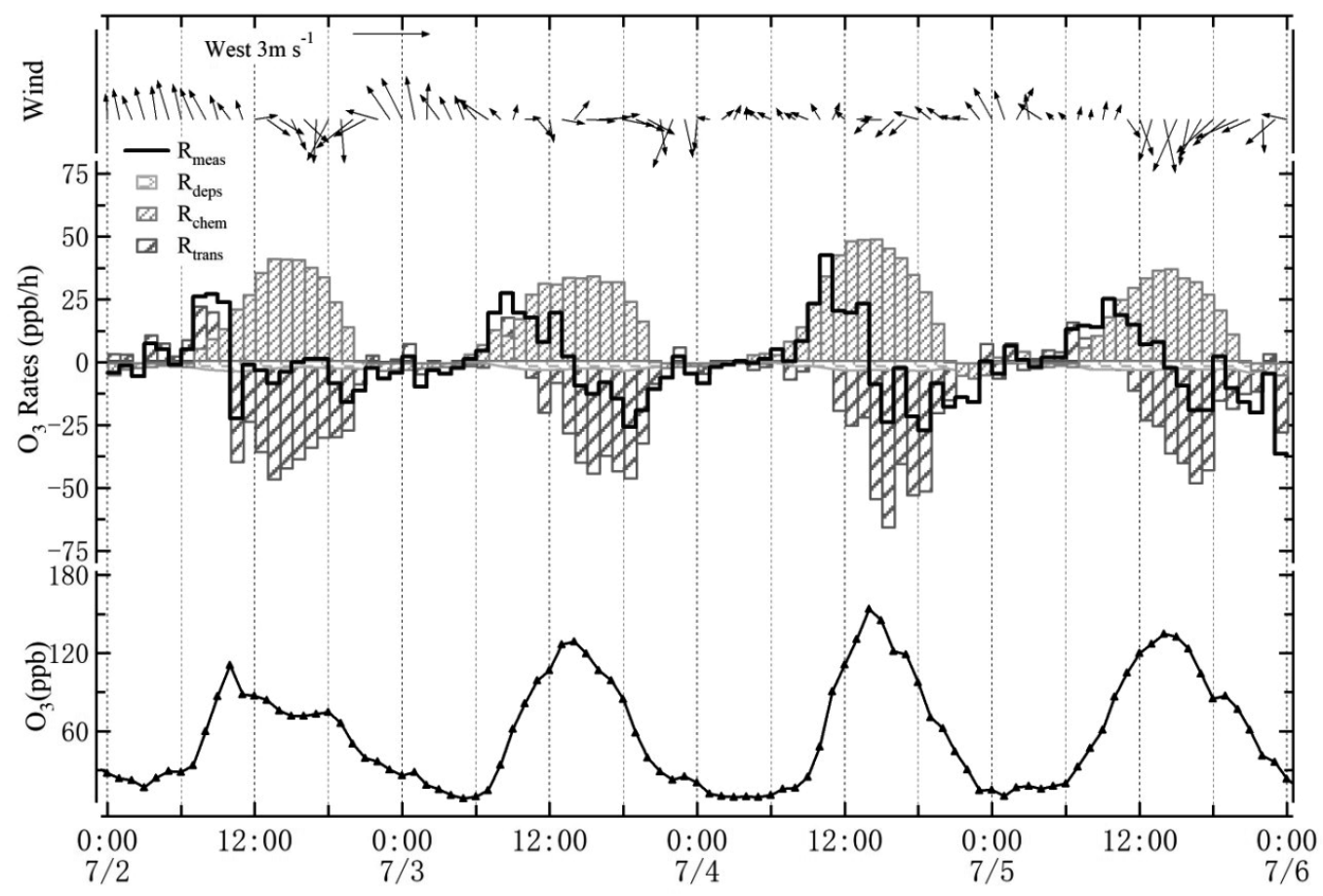

Fig. 6. The time series of $\mathrm{O}_{3}$ and contributions from in situ chemistry, regional transport, and deposition during episodes in Zibo (2-5 July 2018).

from early morning to the $\mathrm{O}_{3}$ maximum, were $\sim 135.2$ to $\sim 155.1 \mathrm{ppbv}$ for these four case study days. Such amounts were higher than the observed $\mathrm{O}_{3}$ build-up of 93.8-144.7 ppbv (see Fig. 6), which were calculated as the increment in $\mathrm{O}_{3}$ concentrations from early morning to the $\mathrm{O}_{3}$ maxima. This indicates that photochemical $\mathrm{O}_{3}$ formation at our study site was sufficiently rapid to lead to the observed $\mathrm{O}_{3}$ increase during the daytime. Moreover, regional transport made a negative contribution to the $\mathrm{O}_{3}$ production rate at this site and may had a potential influence to the downwind regions, which is worthy of further study.

\section{Ozone Formation Regimes}

To diagnose the $\mathrm{O}_{3}$ formation regimes, we performed model sensitivity simulations during four case study days to determine the $\mathrm{O}_{3}$-precursor relationships. $\mathrm{O}_{3}$ precursor relationships were determined by calculating the relative incremental reactivity (RIR), which was defined as the percent change in the net ozone production rates per percent change in target precursors (i.e., VOCs, $\mathrm{NO}_{\mathrm{x}}$, or $\mathrm{CO}$ ) [52]. In this study, we examine the responses of net ozone production rates to reductions by $20 \%$ of VOCs, $\mathrm{NO}_{\mathrm{x}}, \mathrm{CO}$ as well as some particular VOCs groups and species. The modelcalculated RIRs for major $\mathrm{O}_{3}$ precursors and VOC sub-groups at Zibo during the daytime $\mathrm{O}_{3}$ episodes are summarized in Fig. 7. Overall, the $\mathrm{O}_{3}$ formation regimes were similar among these four case study days with some minor differences. VOCs have much higher positive RIR values, with daytime averages (07:00-18:00 LT) of $0.77,0.75,0.80$ and 0.90 on $2-5$ July 2018, respectively, suggesting that reducing VOCs may result in effectively reducing $\mathrm{O}_{3}$ concentrations. The RIRs of $\mathrm{NO}_{\mathrm{x}}$ and $\mathrm{CO}$ were positive but small on all episode days, except for 4 July and 5 July, when the RIRs for NOx were negative. This indicates that NOx emissions reductions may even enhance $\mathrm{O}_{3}$ formation. Therefore, the different RIR values of $\mathrm{NOx}$ on these episodes implied that the $\mathrm{O}_{3}$ formation mechanism varied even at the same site. The ozone formation at Zibo was in a VOC-limited regime or a mixed-control regime. In particular, to further reveal the effects of the VOC subgroups, including alkanes, alkenes and aromatics on $\mathrm{O}_{3}$ formation, their corresponding RIR values were also calculated and shown (see the right panel of Fig. 7). It can be clearly seen that aromatics exhibited the greatest RIR values within the VOCs, i.e., $\sim 0.45, \sim 0.43,0.38$ and $\sim 0.49$ for the four case study days, respectively, suggesting its dominant role in $\mathrm{O}_{3}$ production. Hence, the results suggest that the most efficient way to alleviate the $\mathrm{O}_{3}$ pollution in Zibo is to reduce the aromatics emissions.

Furthermore, the $\mathrm{O}_{3}$ formation regimes in a diurnal cycle may change with respect to the changes of $\mathrm{O}_{3}$ precursors [31, 51]. Fig. 8 depicted the diurnal patterns of major $\mathrm{O}_{3}$ precursors and the VOC sub-groups on episode days at Zibo. This figure clearly illustrates the well-defined diurnal variations of $\mathrm{O}_{3}$ formation regimes for the polluted industrial environments. It can be seen that most RIRs for $\mathrm{O}_{3}$ precursors as well as 

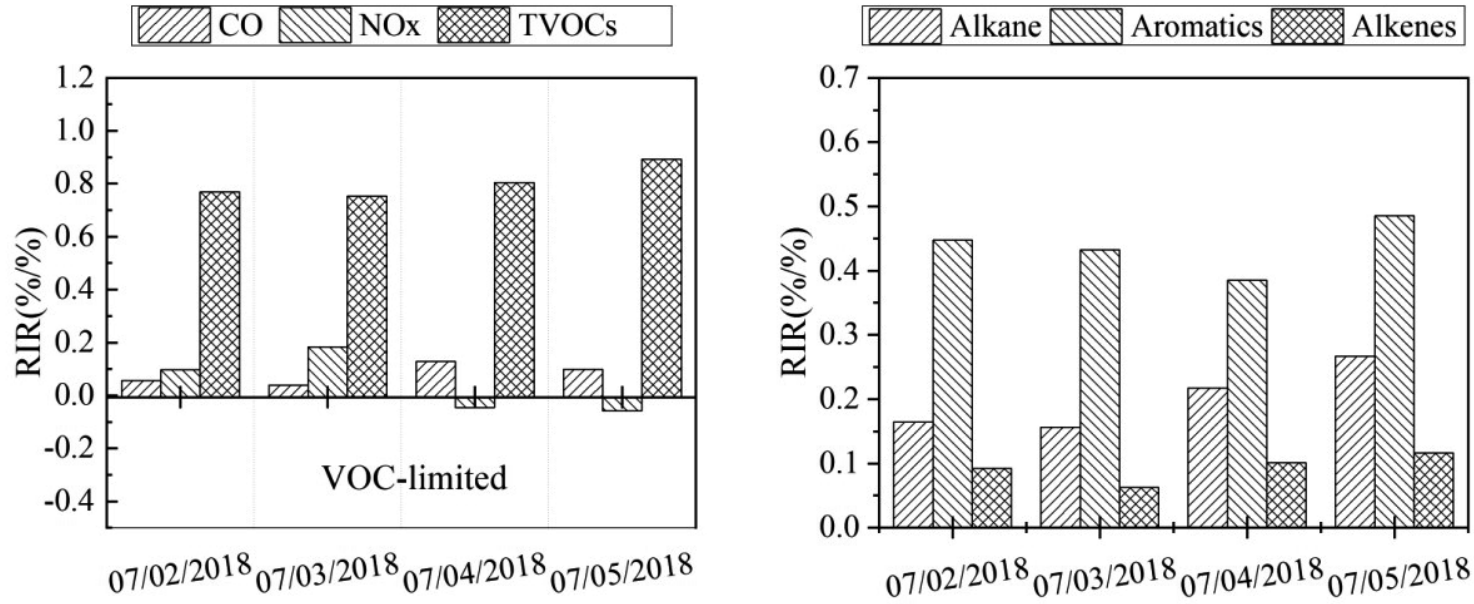

Fig. 7. The OBM-calculated RIRs for major $\mathrm{O}_{3}$ precursors and the VOC sub-groups on 2-5 July, 2018. The left panel shows the RIRs for $\mathrm{NO}_{\mathrm{X}}, \mathrm{CO}$ and VOCs; the right panel shows the RIRs for the VOC sub-groups.

the VOC sub-groups were positive except for the morning negative values (i.e., 08:00-11:00 LT) of NOx, indicating the switched regime from VOCslimited to mixed-control regime. Similar phenomena have also been observed in Zhuhai, Guangdong [51], which ascribed the fresh emissions of NOx from nearby vehicular emissions and household activities in the morning.

In particular, with the explicit mechanism of MCM, the OBM model is capable of identifying the $\mathrm{O}_{3}$ precursors at a species level. To further investigate the relative contribution of the individual aromatics species (in total 12 aromatics had been detected in this study) to the formation of $\mathrm{O}_{3}$, a series of sensitivity model simulations that calculate the RIR values of 12 aromatics in the OBM were also performed.
Fig. 9 shows the model-calculated 12 aromatics RIRs. Of the 12 aromatics, 1,3,5-trimethylbenzene and toluene were found to dominate the total RIR for aromatics. The summed RIR for these two compounds accounted for approximately $75 \%$ to $95 \%$ of the total RIR for aromatics, indicating that they exert the greatest influence on in-situ $\mathrm{O}_{3}$ formation at Zibo. In summary, this suggests that reducing anthropogenic emissions of 1,3,5-Trimethylbenzene and toluene would reduce $\mathrm{O}_{3}$ formation in this industrial atmosphere of China.

Furthermore, a positive matrix factorization (PMF) model conducted on the VOC species was used to identify the contributions of different sources to ambient 1,3,5-Trimethylbenzene and toluene. Five resolved source profiles for these aromatics and related VOCs are shown in Fig. S2. The source profiles of

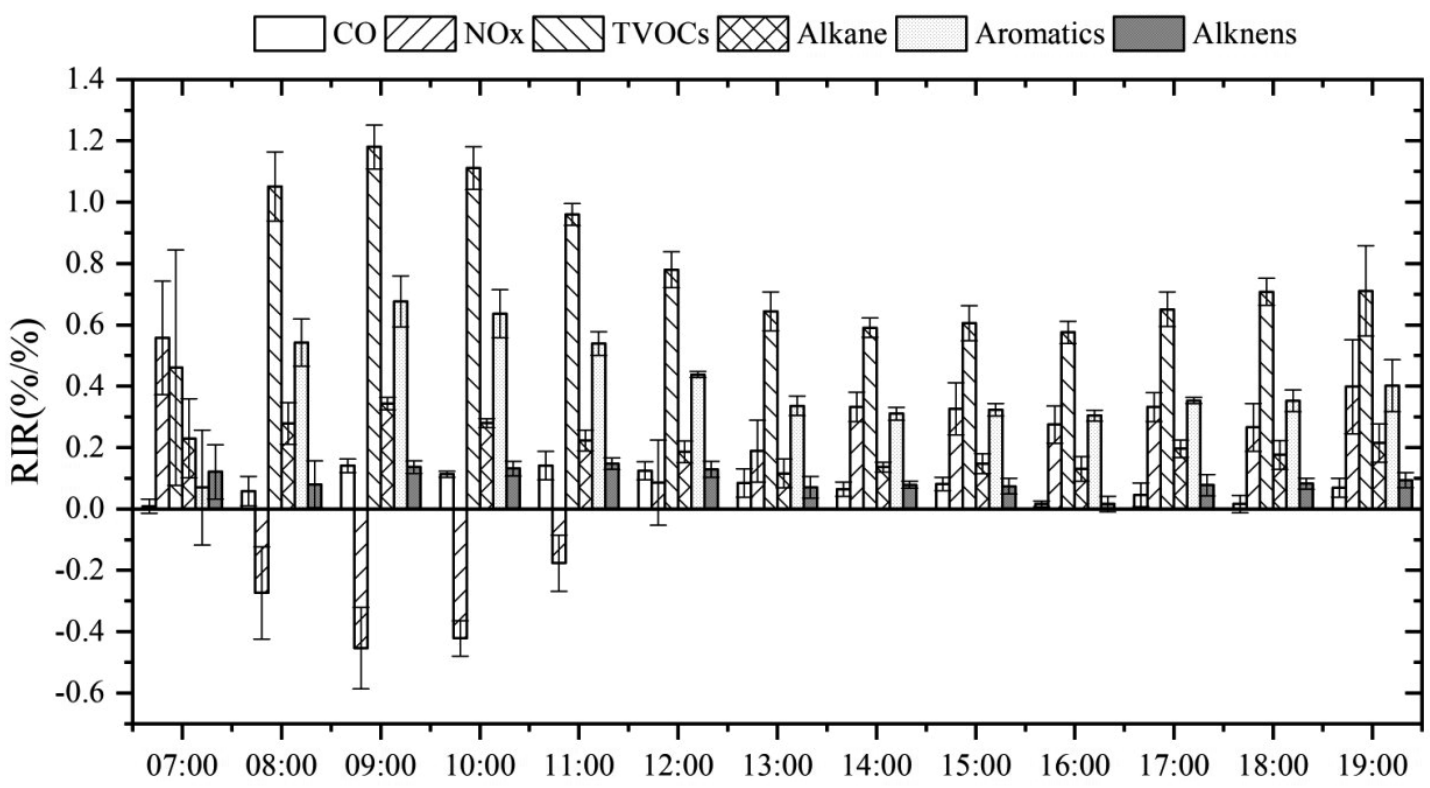

Fig. 8. Average diurnal variation of RIRs for major $\mathrm{O}_{3}$ precursors and the VOC sub-groups at Zibo. The error bars are the standard deviations. 


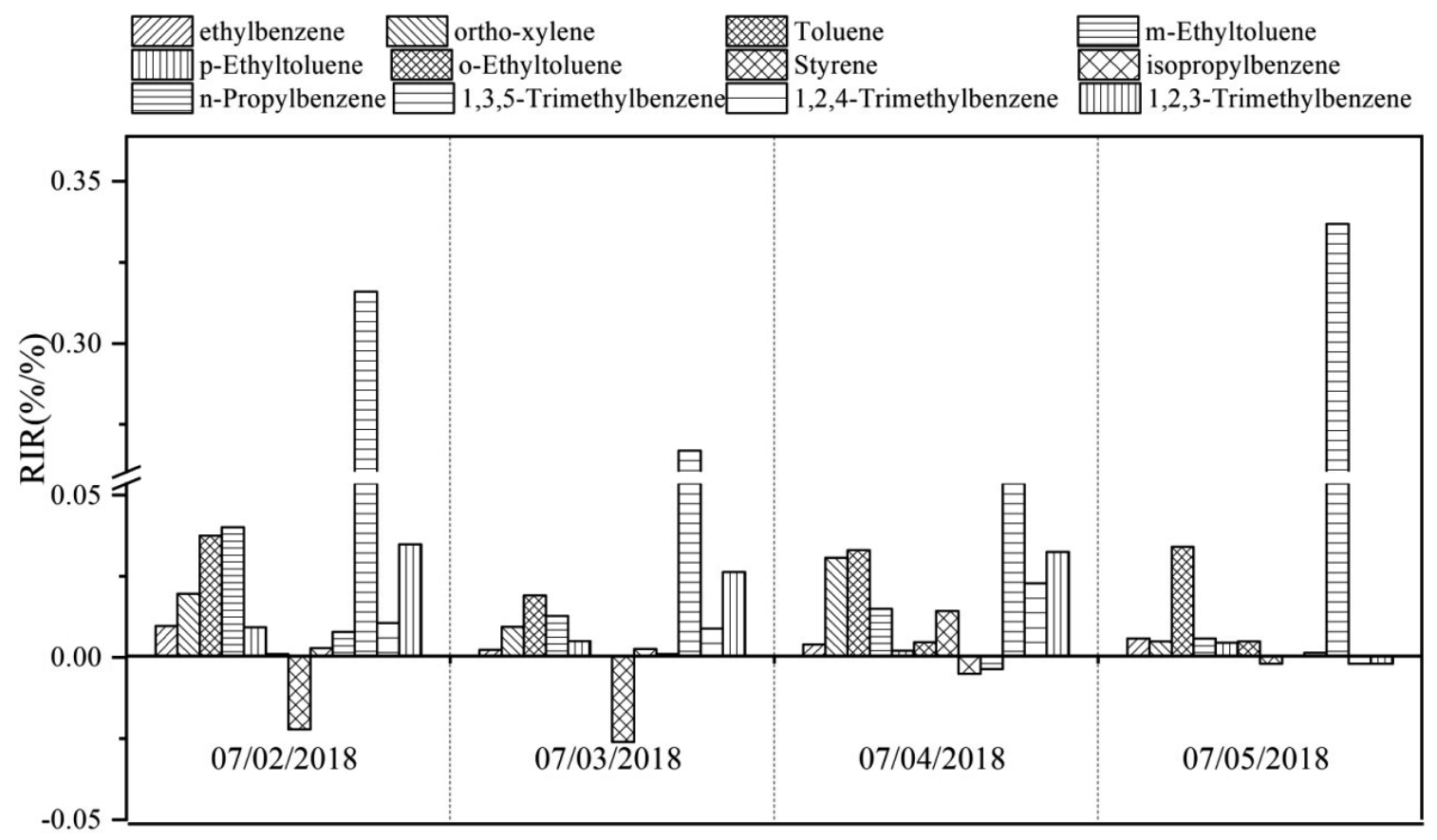

Fig. 9. RIR values of the individual aromatics for $\mathrm{O}_{3}$ formation on 2-5 July, 2018.

these aromatics deduced from PMF analysis showed that 1,3,5-Trimethylbenzene and toluene were mainly emitted from solvents used in industrial processes and vehicular exhaust at Zibo, based on a previous study conducted in France [53, 54] and Brazil [19] . Overall, vehicular emissions, industry and solvent usage were the largest sources of these reactive VOCs. Hence, by reducing emissions of aromatics (from industry and vehicles), the photochemical $\mathrm{O}_{3}$ pollution in the study region would be significantly alleviated.

\section{Conclusions}

Real-time monitoring of VOCs, $\mathrm{O}_{3}$ and related trace gases in the industrial region of Zibo from July 1 to 31,2018 was implemented to improve the understanding of the $\mathrm{O}_{3}$ pollution, as well as VOCs levels, and contributions of VOCs emissions to $\mathrm{O}_{3}$. High $\mathrm{O}_{3}$ concentrations $(>93 \mathrm{ppbv})$ were observed during the early stages of the sampling period. Examinations of diurnal variations illustrate the extensive photochemical $\mathrm{O}_{3}$ formation. The detailed in situ $\mathrm{O}_{3}$ photochemical formation and the ozone-precursors relationships during a severe smog episode at Zibo were analysed by an observation-based box model. The reactions of $\mathrm{NO}+\mathrm{HO}_{2}$ and $\mathrm{NO}+\mathrm{RO}_{2}$ dominated the photochemical formation of $\mathrm{O}_{3}$. The $\mathrm{NO}_{2}$ destroyed via the reactions with $\mathrm{RO}_{2}$ and $\mathrm{OH}$, played an important role in the $\mathrm{O}_{3}$ destruction. Intensive in situ photochemical production during daytime resulted in high $\mathrm{O}_{3}$ levels, and illustrated the potential to export produced $\mathrm{O}_{3}$ to the downwind area.
The OBM-derived RIRs result indicated that the $\mathrm{O}_{3}$ formation was in a VOCs-limited regime or a mixedcontrol regime in Zibo. The VOCs showed the highest RIR, while NOx showed a slight positive and even negative correlation with $\mathrm{O}_{3}$ production. This study found that reducing emissions of 1,3,5-trimethylbenzene and toluene would lead to less $\mathrm{O}_{3}$ production in Zibo, while reducing NOx emissions had little effect and may even increase $\mathrm{O}_{3}$ pollution. In summary, the results of OBM and PMF analyses indicated that controlling the VOC emissions from industrial, solvent use and vehicle exhaust would likely reduce the photochemical $\mathrm{O}_{3}$ pollution in the industrial cluster of Zibo and maybe also apply to other polluted industrial regions of China.

\section{Acknowledgements}

The authors thank Jifeng, Zhao, Chun Ding, Shaoluo, Li and Xuelian, Zhong for their help during the field measurements and data processing. We are grateful to the Master Chemical Mechanism group at the University of Leeds for providing the MCM model. The data analysis and article writing were supported by National Natural Science Foundation of China (No. 42005092), Natural Science Foundation of Shandong Province (No. ZR2020QD058), the Doctoral Research Fund of Shandong Jianzhu University (No. XNBS1936), and the Opening Project of Shanghai Key Laboratory of Atmospheric Particle Pollution and Prevention (LAP3) (No. FDLAP19006). These field measurements were funded by Zibo science and technology development plan project (No. 2016kj010009). 


\section{Conflict of Interest}

The authors declare no conflict of interest.

\section{References}

1. CHAN C.K., YAO X. Air pollution in mega cities in China. Atmos Environ, 42 (1), 1, 2008.

2. INOUE K., TONOKURA K., YAMADA H. Modeling study on the spatial variation of the sensitivity of photochemical ozone concentrations and population exposure to VOC emission reductions in Japan. Air Qual Atmos Heal, 12 (9), 1035, 2019.

3. WANG Y., KONOPKA P., LIU Y., CHEN H., M LLER R., PL GER F., RIESE M., CAI Z., L D. Tropospheric ozone trend over Beijing from 2002-2010: ozonesonde measurements and modeling analysis. Atmos Chem Phys, 12 (18), 8389, 2012.

4. HUANG J., LIU H., CRAWFORD J. H., CHAN C., CONSIDINE D. B., ZHANG Y., ZHENG X., ZHAO C., THOURET V., OLTMANS S.J., LIU S.C., JONES D.B.A., STEENROD S.D., DAMON M.R. Origin of springtime ozone enhancements in the lower troposphere over Beijing: in situ measurements and model analysis. Atmos. Chem. Phys., 15 (9), 5161, 2015.

5. YANG X., XUE L., YAO L., LI Q., WEN L., ZHU Y., CHEN T., WANG X., YANG L., WANG T., LEE S., CHEN J., WANG W. Carbonyl compounds at Mount Tai in the North China Plain: Characteristics, sources, and effects on ozone formation. Atmos Res, 196, 53, 2017.

6. EGHDAMI H., WERNER W., B KER P. Spatio-Temporal Variation of Ozone Concentrations and Ozone Uptake Conditions in Forests in Western Germany. Atmosphere, 11 (11), 1261, 2020.

7. HE K., SHEN Z., SUN J., LEI Y., ZHANG Y., WANG $\mathrm{X}$. Spatial Distribution, Source Apportionment, Ozone Formation Potential, and Health Risks of Volatile Organic Compounds over a Typical Central Plain City in China. Atmosphere, 11 (12), 1365, 2020.

8. WANG X., MANNING W., FENG Z., ZHU Y. Groundlevel ozone in China: distribution and effects on crop yields. Environ Pollut, 147 (2), 394, 2007.

9. WANG T., DING A., GAO J., WU W.S. Strong ozone production in urban plumes from Beijing, China. Geophys Res Lett, 33 (21), 2006.

10. SALVADOR C.M., CHOU C.C.K., HO T.T., TSAI C.Y., TSAO T.M., TSAI M.J., SU T.C. Contribution of Terpenes to Ozone Formation and Secondary Organic Aerosols in a Subtropical Forest Impacted by Urban Pollution. Atmosphere, 11 (11), 1232, 2020.

11. JAN K.R., KELLEROV D., SCHIEBER B. Spatial and Temporal Variations in O3 Concentrations in Western Carpathian Rural Mountain Environments. Polish Journal of Environmental Studies, 24, 2003, 2015.

12. CRUTZEN P. A discussion of the chemistry of some minor constituents in the stratosphere and troposphere. Pure Appl Geophys, 106 (1), 1385, 1973.

13. WANG W., CHAI F., ZHANG K., WANG S., CHEN Y., WANG X., and YANG Y. Study on ambient air quality in Beijing for the summer 2008 Olympic Games. Aerosol Air Qual Res, 1 (1), 31, 2008.

14. TORO A.R., SEGUEL R.J., MORALES S.R.G.E., LEIVA G.M.A. Ozone, nitrogen oxides, and volatile organic compounds in a central zone of Chile. Air Qual Atmos Heal, 8 (6), 545, 2014.

15. GUO H., LING Z.H., CHEUNG K., JIANG F., WANG D.W., SIMPSON I.J., WANG T.J., WANG X.M., SAUNDERS S.M., BLAKE D.R. Characterization of photochemical pollution at different elevations in mountainous areas in Hong Kong. Atmos Chem Phys Discuss, 12 (11), 29025, 2012.

16. XU X., LIN W., WANG T., YAN P. Long-term trend of surface ozone at a regional background station in eastern China 1991-2006: enhanced variability. Atmos Chem Phys, 8 (1), 2595, 2008.

17. GUO H., LING Z H., CHENG H.R., SIMPSON I.J., LYU X.P., WANG X.M., SHAO M., LU H.X., AYOKO G., ZHANG Y.L., SAUNDERS S.M., LAM S.H., WANG J.L., BLAKE D.R. Tropospheric volatile organic compounds in China. Sci Total Environ, 574, 1021, 2017.

18. SO K.L., WANG T. C3-C12 non-methane hydrocarbons in subtropical Hong Kong: spatial-temporal variations, source-receptor relationships and photochemical reactivity. Sci Total Environ, 328 (1-3), 161, 2004.

19. SANTOS E.M., AZEVEDO D.D.A. Impact on groundlevel ozone formation by emission characterization of volatile organic compounds from a flex-fuel light-duty vehicle fleet in a traffic tunnel in Rio de Janeiro, Brazil. Air Qual Atmos Heal, 14 (2), 259, 2020.

20. CAI C., GENG F., TIE X., YU Q., AN J. Characteristics and source apportionment of VOCs measured in Shanghai, China. Atmos. Environ., 44 (38), 5005, 2010.

21. AN J., ZHU B., WANG H., LI Y., LIN X., YANG H. Characteristics and source apportionment of VOCs measured in an industrial area of Nanjing, Yangtze River Delta, China. Atmos. Environ., 97, 206, 2014.

22. WANG T., XUE L., BRIMBLECOMBE P., LAM Y.F., LI L., ZHANG L. Ozone pollution in China: A review of concentrations, meteorological influences, chemical precursors, and effects. Sci. Total Environ., 575, 1582, 2016.

23. WANG M., HU K., CHEN W., SHEN X., LI W., LU $\mathrm{X}$. Ambient Non-Methane Hydrocarbons (NMHCs) Measurements in Baoding, China: Sources and Roles in Ozone Formation. Atmosphere, 11 (11), 1205, 2020.

24. EDWARDS P.M., BROWN S.S., ROBERTS J.M., AHMADOV R., BANTA R.M., DEGOUW J.A., DUBE W.P., FIELD R.A., FLYNN J.H., GILMAN J.B., GRAUS M., HELMIG D., KOSS A., LANGFORD A.O., LEFER B.L., LERNER B.M., LI R., LI S.M., MCKEEN S.A., MURPHY S.M., PARRISH D.D., SENFF C.J., SOLTIS J., STUTZ J., SWEENEY C., THOMPSON C.R., TRAINER M.K., TSAI C., VERES P.R., WASHENFELDER R.A., WARNEKE C., WILD R.J., YOUNG C.J., YUAN B., ZAMORA R. High winter ozone pollution from carbonyl photolysis in an oil and gas basin. Nature, 514 (7522), 351, 2014.

25. KANAYA Y., POCHANART P., LIU Y., LI J., TANIMOTO H., KATO S., SUTHAWAREE J., INOMATA S., TAKETANI F., OKUZAWA K. Rates and regimes of photochemical ozone production over Central East China in June 2006: a box model analysis using comprehensive measurements of ozone precursors. Atmos Chem Phys, 9 (20), 7711, 2009.

26. XUE L.K., WANG T., GAO J., DING A.J., ZHOU X.H., BLAKE D.R., WANG X.F., SAUNDERS S.M., FAN S.J., ZUO H.C., ZHANG Q.Z., aWANG W.X. Groundlevel ozone in four Chinese cities: precursors, regional transport and heterogeneous processes. Atmos Chem Phys, 14, 13175, 2014. 
27. ZHANG J., WANG T., CHAMEIDES W., CARDELINO C., KWOK J., BLAKE D., DING A., SO K. Ozone production and hydrocarbon reactivity in Hong Kong, Southern China. Atmos Chem Phys, 7 (2), 557, 2007.

28. CHENG H., GUO H., WANG X., SAUNDERS S.M., LAM S.H., JIANG F., WANG T., DING A., LEE S., HO $\mathrm{K} F$. On the relationship between ozone and its precursors in the Pearl River Delta: application of an observationbased model (OBM). Environ Sci Pollut Res Int, 17 (3), 547, 2010.

29. LYU X.P., CHEN N., GUO H., ZHANG W.H., WANG N., WANG Y., LIU M. Ambient volatile organic compounds and their effect on ozone production in Wuhan, central China. Sci Total Environ, 541, 200, 2016.

30. HUANG Y., HO S.S., HO K.F., LEE S.C., YU J.Z., LOUIE P.K. Characteristics and health impacts of VOCs and carbonyls associated with residential cooking activities in Hong Kong. J Hazard Mater, 186 (1), 344, 2011.

31. ZOU Y., DENG X.J., ZHU D., GONG D.C., WANG H., LI F., TAN H.B., DENG T., MAI B.R., LIU X.T., WANG B.G. Characteristics of 1 year of observational data of VOCs, $\mathrm{NOx}$ and $\mathrm{O}_{3}$ at a suburban site in Guangzhou, China. Atmos. Chem. Phys., 15 (12), 6625, 2015.

32. JENKIN M.E., SAUNDERS S.M., WAGNER V., PILLING M.J. Protocol for the development of the Master ChemicalMechanism, MCMv3 (Part B): tropospheric degradation of aromatic volatile organic compounds. Atmos. Chem. Phys., 3, 181, 2003.

33. JENKIN M.E., YOUNG J.C., RICKARD A.R. The MCM v3.3 degradation scheme for isoprene. Atmos. Chem. Phys. Diss., 15, 9709, 2015.

34. XUE L., WANG T., WANG X., BLAKE D.R., GAO J., NIE W., GAO R., GAO X., XU Z., DING A., HUANG Y., LEE S., CHEN Y., WANG S., CHAI F., ZHANG Q., WANG W. On the use of an explicit chemical mechanism to dissect peroxy acetyl nitrate formation. Environ Pollut, 195, 39, 2014

35. YANG X., ZHANG G., SUN Y., ZHU L., WEI X., LI Z., ZHONG X. Explicit modeling of background HCHO formation in southern China. Atmos. Res., 240, 104941, 2020.

36. YANG X., XUE L., WANG T., WANG X., GAO J., LEE S., BLAKE D.R., CHAI F., WANG W. Observations and explicit modeling of summertime carbonyl formation in Beijing: Identification of key precursor species and their impact on atmospheric oxidation chemistry. J. Geophys. Res. Atmos., 123 (12-14), 2018.

37. XUE L.K., WANG T., GUO H., BLAKE D.R., TANG J., ZHANG X.C., SAUNDERS S.M., WANG W.X. Sources and photochemistry of volatile organic compounds in the remote atmosphere of western China results from the Mt.Waliguan Observatory. Atmos Chem Phys, 13 (17), 8551, 2013.

38. ZHANG L., BROOK J. R., VET R. A revised parameterization for gaseous dry deposition in air-quality models. Atmos Chem Phys, 3 (2), 2067, 2003.

39. XUE L., WANG T., LOUIE P.K., LUK C.W., BLAKE D. R., XU Z. Increasing external effects negate local efforts to control ozone air pollution: a case study of Hong Kong and implications for other Chinese cities. Environ. Sci. Technol., 48 (18), 10769, 2014.

40. ZHANG Y., LI R., FU H., ZHOU D., CHEN J. Observation and analysis of atmospheric volatile organic compounds in a typical petrochemical area in Yangtze River Delta, China. J Environ Sci (China), 71, 233, 2018.
41. ZONG R., YANG X., LIANG W., XU C., ZHU Y., CHEN T., YAO L., WANG L., ZHANG J., YANG L. Strong ozone production at a rural site in the North China Plain: Mixed effects of urban plumes and biogenic emissions. J Environ Sci-China, 71 (9), S1001074217336616, 2018.

42. GALVAO E.S., SANTOS J.M., REIS JUNIOR N.C., STUETZ R.M. Volatile organic compounds speciation and their influence on ozone formation potential in an industrialized urban area in Brazil. Environ. Technol., 37 (17), 2133, 2016.

43. LEUCHNER M., RAPPENGL CK B. VOC sourcereceptor relationships in Houston during TexAQS-II. Atmos Environ, 44 (33), 4056, 2010.

44. SHAO P., AN J., XIN J., WU F., WANG J., JI D., WANG Y. Source apportionment of VOCs and the contribution to photochemical ozone formation during summer in the typical industrial area in the Yangtze River Delta, China. Atmos. Res., 176-177, 64, 2016.

45. ZHOU X., LI Z., ZHANG T., WANG F., WANG F., TAO Y., ZHANG X., WANG F., HUANG J. Volatile organic compounds in a typical petrochemical industrialized valley city of northwest China based on high-resolution PTR-MS measurements: Characterization, sources and chemical effects. Sci Total Environ, 671, 883, 2019.

46. XU J., MA J.Z., ZHANG X.L., XU X.B., XU X.F., LIN W.L., WANG Y., MENG W., MA Z.Q. Measurements of ozone and its precursors in Beijing during summertime: impact of urban plumes on ozone pollution in downwind rural areas. Atmos Chem Phys, 11, 12241, 2011.

47. HAN S.Q., ZHANG M., ZHAO C.S., LU X.Q., RAN L., HAN M., LI P.Y., LI X.J. Differences in ozone photochemical characteristics between the megacity Tianjin and its rural surroundings. Atmos. Environ., 79, 209, 2013.

48. GUO H., CHENG H.R., LING Z.H., LOUIE P.K., AYOKO G.A. Which emission sources are responsible for the volatile organic compounds in the atmosphere of Pearl River Delta? J Hazard Mater, 188 (1-3), 116, 2011.

49. WEN L., XUE L., WANG X., XU C., CHEN T., YANG L., WANG T., ZHANG Q., WANG W. Summertime fine particulate nitrate pollution in the North China Plain: increasing trends, formation mechanisms and implications for control policy. Atmos Chem Phys, 18 (15), 11261, 2018.

50. WANG L., WANG X., GU R., WANG H., YAO L., WEN L., ZHU F., WANG W., XUE L., YANG L., LU K., CHEN J., WANG T., ZHANG Y., WANG W. Observations of fine particulate nitrated phenols in four sites in northern China: concentrations, source apportionment, and secondary formation. Atmos Chem Phys, 18 (6), 4349, 2018.

51. LIU X., WANG N., LYU X., ZEREN Y., JIANG F., WANG X., ZOU S., LING Z., GUO H. Photochemistry of ozone pollution in autumn in Pearl River Estuary, South China. Sci. Total Environ., 754, 141812, 2021.

52. CARDELINO C.A., CHAMEIDES W.L. An ObservationBased Model for Analyzing Ozone Precursor Relationships in the Urban Atmosphere. J. Air \& Waste Manage. Assoc., 45 (3), 161, 1995.

53. BORBON A., LOCOGE N., VEILLEROT M., GALLOO J.C., GUILLERMO R. Characterisation of NMHCs in a French urban atmosphere: overview of the main sources. Sci Total Environ, 292 (3), 177, 2002.

54. DUMANOGLU Y., KARA M., ALTIOK H., ODABASI M., ELBIR T., BAYRAM A. Spatial and seasonal variation and source apportionment of volatile organic compounds (VOCs) in a heavily industrialized region. Atmos Environ, 98, 168, 2014. 


\section{Supplementary Material}

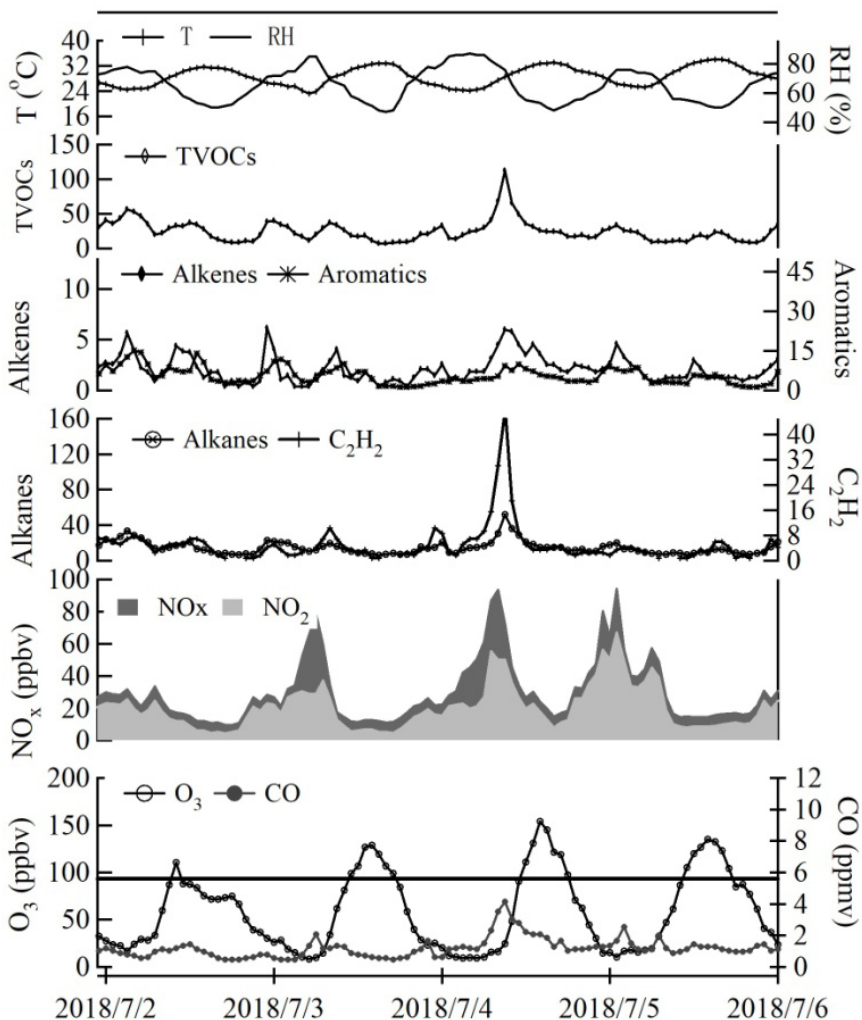

Fig. S1. Time series of $\mathrm{O}_{3}$, related pollutants and meteorological conditions at Zibo between 2 and 5 July 2018 .
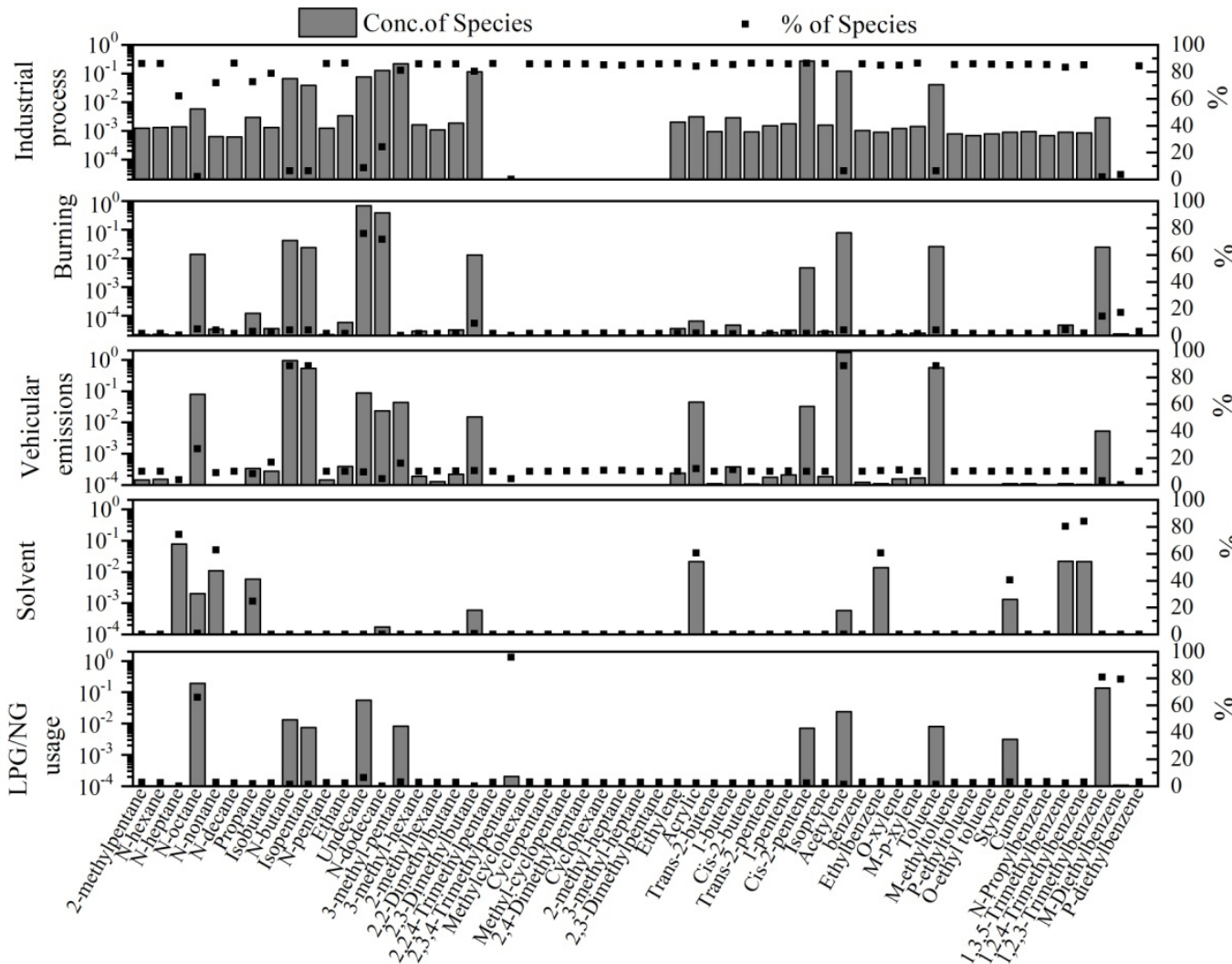

Fig. S2. Source profiles of 1,3,5-Trimethylbenzene, toluene and other VOC species deduced from PMF analysis. 


\section{PMF Model}

PMF is a factor-based receptor model based on multivariate statistical methods that decompose a matrix of sample date into matrices. In this study, $744 \times 55$ matrix date $($ VOCs number $\times 55$ species) sets were introduced to PMF 5.0 to identify 1,3,5-Trimethylbenzene and toluene sources in Zibo. The detailed model settings and physical parameterizations can be found in the user manual [1]. Five resolved source profiles for 1,3,5-Trimethylbenzene, toluene and related VOCs in Zibo are shown in Fig. S2. The first factor was characterized by high amounts of Alkenes and Aromatics, suggesting its relation to industrial process [2]. Based on the high undecane and n-dodecane levels, which were important markers for burning, factor 2 was identified as burning [3, 4]. The third factor was identified as vehicular emissions, represented by high load of n-butane, iso-pentane, acetylene and toluene. These VOCs had been commonly recognized to be markers of vehicle emissions [4, 5]. As to the fourth factor, the solvent usage was distinguished by high amounts of Ethyl-benzene, 1,3,5-Trimethylbenzene and 1,2,4-Trimethylbenzene [6]. Finally, The high loadings of N-octane combined with 1,2,3-trimmethylbenzene indicated that factor 5 was related to LPG/NG usage [4]. Obviously, among these derived profiles of each factor, vehicular emissions were important sources of toluene. Solvent usage as well as industrial process emitted large amount of 1,3,5-Trimethylbenzene. Thus, vehicular emissions, industry and solvent usage were the major sources of 1,3,5-Trimethylbenzene and toluene.

\section{Reference}

1. EPA U. Positive Matrix Factorization (PMF) 5.0 Fundamentals \& User Guide. Office of Research and Development, 2014.

2. HE K., SHEN Z., SUN J., LEI Y., ZHANG Y., WANG $X$. Spatial Distribution, Source Apportionment, Ozone Formation Potential, and Health Risks of Volatile Organic Compounds over a Typical Central Plain City in China. Atmosphere, 11 (12), 1365, 2020.

3. LUO H., LI G., CHEN J., LIN Q., AN T. Spatial and temporal distribution characteristics and ozone formation potentials of volatile organic compounds from three typical functional areas in China. Environ Res, 183, 109141, 2020.

4. LIU Y., SHAO M., FU L., LU S., ZENG L., TANG D. Source profiles of volatile organic compounds (VOCs) measured in China: Part I. Atmos Environ, 42 (25), 6247, 2008.

5. SANTOS E.M., AZEVEDO D.D.A. Impact on groundlevel ozone formation by emission characterization of volatile organic compounds from a flex-fuel light-duty vehicle fleet in a traffic tunnel in Rio de Janeiro, Brazil. Air Qual Atmos Heal, 14 (2), 259, 2020.

6. YUAN B., SHAO M., DE GOUW J., PARRISH D. D., LU S., WANG M., ZENG L., ZHANG Q., SONG Y., ZHANG J., et al. Volatile organic compounds (VOCs) in urban air: How chemistry affects the interpretation of positive matrix factorization (PMF) analysis. J Geophys Res Atmos, 117 (D24), 24302, 2012. 
